\title{
ANALISIS RISIKO CEMARAN MIKROBIOLOGIS PADA PENGELOLAAN PERALATAN MAKAN DAN MINUM DI KANTIN SEKOLAH DASAR
}

\author{
Regina Haris Christiva ${ }^{1}$, Rusmiati ${ }^{2 *}$, Setiawan $^{3}$ \\ 1,2,3 Department of Environmental Health, Poltekkes Kemenkes Surabaya.
}

\section{Artikel Info :}

Received 2 Agutus 2020

Accepted 18 Agustus 2020

Available online 24 Agustus 2020

Editor: Ahmad Fikri

Key word :

HACCP, Eating and drinking utensils, Cafetaria, Risk

Kata Kunci :

HACCP, Peralatan makan dan minum, kantin, Risiko

Ruwa Jurai: Jurnal Kesehatan Lingkungan is licensed under a Creative Commons AttributionNonCommercial 4.0 International License.

\footnotetext{
${ }^{*}$ Corresponding author : Rusmiati

Jl. Pucang Jajar Tengah No.56, Kertajaya, Kec. Gubeng, Kota Surabaya, Jawa Timur

Email : rustig63@gmail.com
}

\begin{abstract}
A b st ract
Food services must pay attention to a proper sanitary and hygiene practices, including on the eating and drinking utensils used in school cafetaria. Eating and drinking utensils management must prevent contamination, so it does not pose any risks of adverse health effect to the students. Preliminary test showed that the glass swab sample total plate count result was $2.894,6 \mathrm{CFU} / \mathrm{cm}^{2}$, thus it did not comply to the health regulation. This research aims to analyze the risks of managing eating and drinking utensils in the school cafetaria using the HACCP method by determining its critical control points (CCPs). This is an observasional study in which the object was two state elementary school cafetaria in Pakis Village, Sawahan region, Surabaya. Data was collected through observations, interviews, and samplings. Total plate count was measured on the utensils swab samples, while E.coli and total coliform was counted on the washing water samples. Based on the HACCP approach, the equipment management flow starts with handwashing, followed by using, washing and storing utensils. As from the result suggested, it is known that there are microbiological hazards in the utensils management, causes of risks originated from the utensils management, there are necessary control measures, CCPs are identified in the utensils management flow, and equipment management is able to pose risks of contamination and disease transmission. Causes of risks from the utensils management include washing water microbiological quality and inadequate washing stage. The necessary control measures can be applied to the identified CCPs, namely at the scraping, washing, rinsing, sanitizing, and drying stages.
\end{abstract}

Penyediaan pangan harus memperhatikan higiene dan sanitasi yang baik, termasuk pada peralatan makan dan minum yang digunakan pada kantin sekolah. Pengelolaan peralatan makan dan minum di kantin sekolah harus mencegah peralatan terkontaminasi dan menimbulkan risiko gangguan kesehatan bagi siswa sebagai konsumen. Hasil uji pendahuluan pada sampel usap gelas menunjukkan angka kuman yang tidak memenuhi syarat, yaitu sebanyak $2.894,6 \mathrm{koloni} / \mathrm{cm}^{2}$. Tujuan penelitian adalah menganalisis risiko pada pengelolaan peralatan makan dan minum di kantin sekolah dasar menggunakan metode Hazard Analysis Critical Control Point (HACCP) dengan menentukan titik kendali kritisnya (TKK). Penelitian ini merupakan penelitian observasional dengan objek penelitian meliputi dua kantin sekolah dasar negeri di wilayah Kelurahan Pakis, Kecamatan Sawahan, Kota Surabaya. Pengumpulan data dilakukan dengan observasi, wawancara, dan pengambilan sampel. Pengukuran angka kuman dilakukan terhadap sampel usap peralatan, sedangkan pengukuran kandungan E.coli dan total coliform dilakukan terhadap sampel air pencucian peralatan. Berdasarkan pendekatan HACCP yang dilakukan, alur pengelolaan peralatan dimulai dari pencucian tangan penjamah, kemudian diikuti dengan penggunaan, pencucian, dan penyimpanan peralatan. Dari hasil penelitian, diketahui bahwa terdapat bahaya mikrobiologis pada pengelolaan peralatan, penyebab terjadinya risiko berasal dari alur pengelolaan peralatan, terdapat tindakan pengendalian yang diperlukan, TKK teridentifikasi pada seluruh alur pengelolaan peralatan, dan pengelolaan peralatan mampu menghadirkan risiko kontaminasi serta risiko penularan penyakit. Penyebab terjadinya risiko dari proses pencucian antara lain yaitu kualitas mikrobiologis air pencucian dan tahap pencucian yang tidak adekuat. Tindakan pengendalian yang diperlukan dapat diterapkan pada TKK yang telah teridentifikasi, yaitu pada tahap scraping, washing, rinsing, sanitizing, dan drying. 


\section{PENDAHULUAN}

Kejadian luar biasa (KLB) keracunan pangan merupakan permasalahan terkait penyakit bawaan pangan (food-borne diseases) yang masih menjadi masalah kesehatan masyarakat di Indonesia. Hasil pemeriksaan BPOM (2017) menunjukkan bahwa terdapat banyak kasus KLB keracunan pangan terjadi di lembaga pendidikan, khususnya tingkat Sekolah Dasar/Madrasah Ibtidaiyah (SD/MI). Penyakit bawaan pangan disebabkan oleh konsumsi pangan yang telah terkontaminasi (Adley dan Ryan, 2016), di mana salah satu penyebab kontaminasi pangan adalah peralatan makan dan minum yang tidak memenuhi persyaratan kesehatan. Permenkes RI No. 1096 Tahun 2011 menyatakan bahwa angka kuman peralatan makan dan minum harus 0 (nol) koloni/ $\mathrm{cm}^{2}$ dan permukaannya tidak boleh gompal, retak, ataupun kasar. Kontaminasi peralatan makan dan minum dapat berasal dari praktik higiene dan sanitasi peralatan yang tidak tepat, baik pada proses pencucian, pengeringan, maupun penyimpanan (Yushananta \& Usman, 2018).

Kantin sekolah di Kota Surabaya mulai menggunakan peralatan makan dan minum yang dapat dipakai kembali, sebagai bentuk pengelolaan kantin untuk mendukung kebijakan "Surabaya Zero Waste" di sekolah (Astri dan Hariyati, 2018). Peralatan makan dan minum yang tidak ditangani dengan baik akan menyediakan lingkungan yang memadai bagi pertumbuhan agent biologis, sehingga kontaminasi pangan dapat terjadi ketika permukaan peralatan bersentuhan dengan pangan. Patogen seperti S.aureus, S.typhi, E.coli, dan Shigella dapat terakumulasi pada permukaan peralatan dan menjadi sumber penularan penyakit dari satu orang ke orang lainnya (Maori \& De, 2010).

Pengelolaan peralatan makan dan minum berpotensi menghadirkan bahaya (hazards) yang memiliki risiko keamanan pangan, karena kualitas peralatan dapat memengaruhi kualitas pangan yang disajikan. Risiko keamanan pangan harus dikendalikan agar tidak menimbulkan dampak merugikan berupa gangguan kesehatan, untuk itu dapat dilakukan analisis risiko dengan pendekatan Hazard Analysis Critical Control Point (HACCP) yang mampu mengidentifikasi titik-titik kendali kritis pada pengelolaan peralatan. Hasil analisis risiko menyediakan pertimbangan yang memadai untuk menentukan tindakan penanganan yang sesuai dengan bahaya dan risiko yang dihadapi.

Berdasarkan hasil observasi awal di kantin sekolah dasar negeri wilayah Kecamatan Sawahan, diketahui adanya pengeringan peralatan makan dan minum dengan lap kain/serbet yang kotor, perilaku penjamah mengusapkan tangan pada pakaian, dan kurangnya tempat pencucian peralatan/sink. Didapati pula adanya gelas habis pakai yang tidak dicuci sebelum digunakan kembali untuk siswa lainnya dengan angka kuman tidak memenuhi syarat, yaitu sebanyak 2.894,6 koloni $/ \mathrm{cm}^{2}$. Penelitian bertujuan untuk menganalisis risiko biologis dalam pengelolaan peralatan makan dan minum di kantin sekolah dasar negeri wilayah Kelurahan Pakis, Kecamatan Sawahan, Kota Surabaya pada tahun 2020 dengan pendekatan HACCP.

\section{METODE}

Penelitian bersifat observasional menggunakan desain pengumpulan data cross-sectional. Penelitian dilakukan di kantin SDN Pakis III dan SDN Pakis $V$ Kota Surabaya dengan kantin sekolah sebagai objek penelitian. Variabel yang diteliti meliputi variabel bahaya biologis, risiko, penyebab, tindakan pengendalian yang diperlukan, titik kendali kritis, dan variabel analisis risiko.

Pengumpulan data dilakukan melalui observasi, wawancara, serta pengambilan sampel. Pengukuran angka kuman dilakukan terhadap sampel usap peralatan, sedangkan pengukuran kandungan E.coli dan total coliform dilakukan terhadap sampel air pencucian peralatan. Analisis data dilakukan secara deskriptif dengan menganalisis risiko terkait pengelolaan peralatan makan dan minum di kantin sekolah menggunakan pendekatan HACCP untuk menentukan critical control point atau titik kendali kritis (TKK). Penelitian ini dinyatakan layak etik oleh KEPK Poltekkes Kemenkes Surabaya dengan nomor sertifikat No.EA/195/KEPK-Poltekkes_Sby/N/2020. 


\section{HASIL}

Hasil observasi menunjukkan bahwa kegiatan pengelolaan peralatan yang dilakukan di kedua kantin sekolah meliputi pencucian tangan penjamah makanan, penggunaan/penanganan peralatan, proses pencucian peralatan (termasuk fasilitas pencuciannya), dan penyimpanan peralatan. Analisis risiko dalam penelitian ini menggunakan kerangka kerja pada Prinsip 1 dan Prinsip 2 dari HACCP, yang meliputi identifikasi bahaya, identifikasi penyebab dan tindakan pengendalian yang diperlukan, serta identifikasi TKK.

1. Identifikasi Bahaya Biologis

Identifikasi bahaya biologis/mikrobiologis pada pengelolaan peralatan makan dan minum di kantin sekolah dilakukan melalui pemeriksaan laboratorium sejumlah sampel. Hasil pemeriksaan yang dilakukan di Laboratorium Kesehatan Daerah Gayungsari Kota Surabaya terlihat pada Tabel 1.

Tabel 1. Hasil Pemeriksaan Usap Alat dan Air Pencucian Peralatan

\begin{tabular}{llllll}
\hline Jenis Sampel & Parameter & Asal Sampel & $\begin{array}{l}\text { Hasil } \\
\text { Pemeriksaan }\end{array}$ & Batas Maksimal & Kategori \\
\hline \multirow{2}{*}{ Usap sendok } & Angka kuman & SDN Pakis III & 24 CFU & 0 & TMS \\
Usap & (ALT) & SDN Pakis V & 21 CFU & 0 & TMS \\
mangkuk & Angka kuman & SDN Pakis III & 24 CFU & 0 & TMS \\
Usap gelas & (ALT) & SDN Pakis V & 16 CFU & 0 & TMS \\
& Angka kuman & SDN Pakis III & Tidak terhitung & 0 & TMS \\
\multirow{4}{*}{ Air pencu-cian } & ELT) & SDN Pakis V & Tidak terhitung & 0 & TMS \\
peralatan & \multirow{2}{*}{ Total Coliform } & SDN Pakis III & 2 CFU & 0 & TMS \\
& & SDN Pakis V & 0 CFU & 0 & MS \\
& & SDN Pakis III & 27 CFU & 50 CFU & MS \\
\hline
\end{tabular}

2. Identifikasi Penyebab dan Tindakan

Pengendalian yang Diperlukan

Identifikasi penyebab terjadinya risiko dan tindakan pengendalian yang diperlukan dilakukan berdasarkan alur pengelolaan peralatan di kedua kantin sekolah. Gambar 1 merupakan alur pengelolaan peralatan makan dan minum yang dilakukan di kantin SDN Pakis III dan SDN Pakis V Surabaya.

Dari alur tersebut, hanya proses pencucian peralatan yang akan dianalisis lebih lanjut dalam artikel ini. Tabel 2 merupakan hasil identifikasi penyebab terjadinya risiko dan tindakan pengendalian di kedua kantin

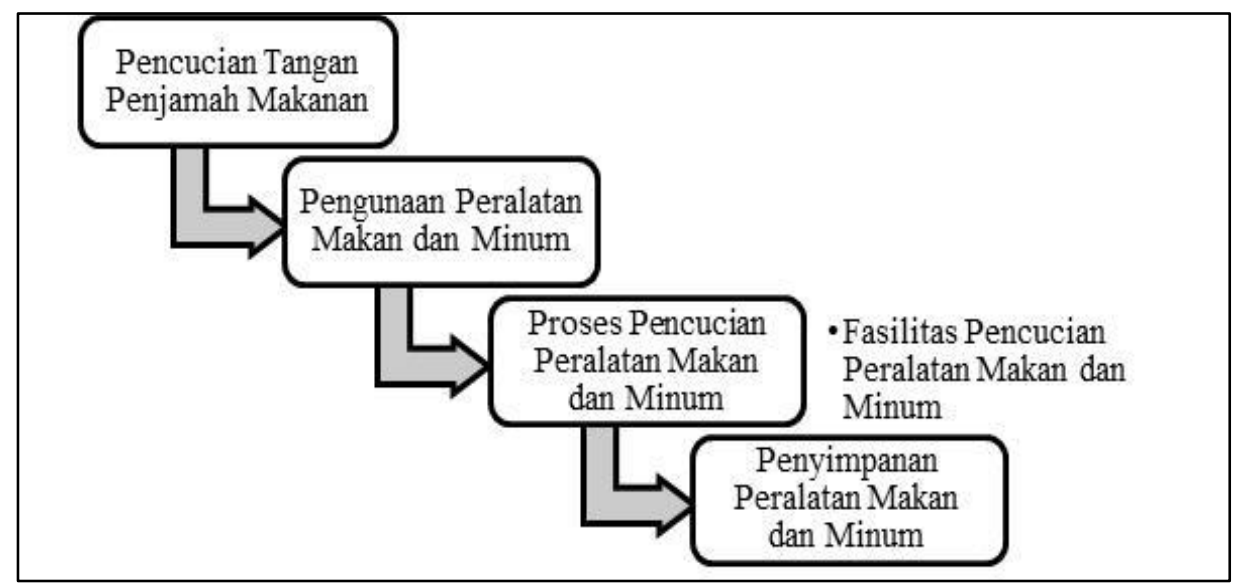

Gambar 1. Alur pengelolaan peralatan makan dan minum di kantin SDN Pakis III dan SDN Pakis V Surabaya 
3. Analisis Risiko Pengelolaan Peralatan Makan dan Minum

Pohon Keputusan (Gambar 2) digunakan untuk menentukan TKK dari tiap tahap pengelolaan peralatan yang dilakukan.

Analisis risiko melalui pendekatan HACCP dilakukan dengan menganalisis bahaya yang ada, penyebab bahaya dapat menimbulkan risiko, serta tindakan pengendalian yang diperlukan untuk menjawab pertanyaan dalam Pohon Keputusan. Penentuan TKK harus disertai alasan yang sesuai dengan kondisi nyata di lokasi untuk memperkuat pengambilan keputusan mengenai suatu tahapan/proses/kondisi termasuk TKK atau bukan TKK. TKK wajib dikendalikan untuk mengurangi/mencegah terjadinya risiko kontaminasi dan penularan penyakit. Analisis risiko pengelolaan peralatan makan dan minum pada proses pencucian tampak pada Tabel 3 .

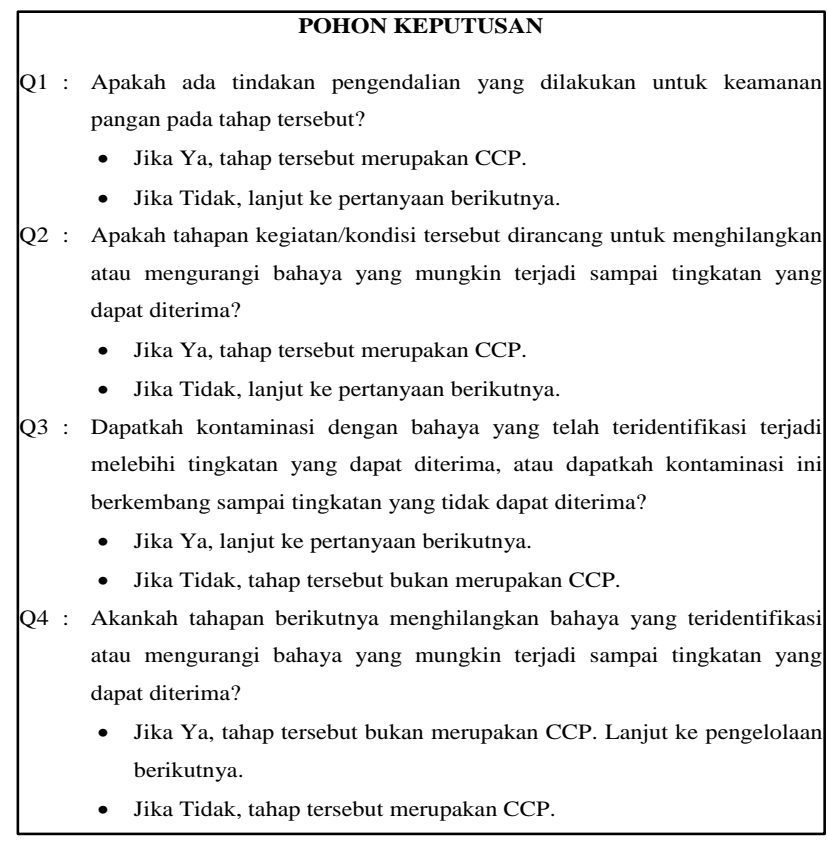

Gambar 2. Pohon Keputusan

\section{PEMBAHASAN}

1. Identifikasi Bahaya Biologis

Dari hasil pemeriksaan laboratorium (Tabel 1), diketahui bahwa terdapat bahaya mikrobiologis berupa angka kuman pada peralatan makan dan minum kedua kantin sekolah serta E.coli pada air pencucian peralatan kantin SDN Pakis III Surabaya. Adanya bahaya mikrobiologis pada pengelolaan peralatan tersebut tidak memenuhi syarat berdasarkan Permenkes No. 1096 Tahun
2011 dan Permenkes No. 32 Tahun 2017. Berbagai penelitian menyimpulkan bahwa masih banyak peralatan makan dan minum yang tidak memenuhi persyaratan mikrobiologis, seperti mengandung angka kuman melebihi syarat, E.coli, S.aureus, Klebsiella sp., Salmonella sp., Proteus sp., Shigella sp., Bacillus sp., dan Clostridium (Maori \& De, 2010; Sopandi \& Wardah, 2014; Marisdayana et al., 2017).

Beberapa patogen pada permukaan tangan manusia dapat menyebar pada objek-objek yang disentuhnya. Purwanti et al. (2015) menyimpulkan $66,7 \%$ sampel usap tangan penjamah makanan di kantin terkontaminasi. Patogen-patogen yang teridentifikasi pada permukaan tangan penjamah makanan memiliki kemiripan dengan patogen yang teridentifikasi pada permukaan peralatan makan dan minum, seperti S.aureus, E.coli, Klebsiella, dan Proteus vulgaris (Ray et al., 2011; Ogba et al., 2018).

Demikian pula dengan patogen yang teridentifikasi pada fasilitas pencucian seperti sink, spons, dan lap kain/serbet yang digunakan mengelap peralatan, antara lain yaitu S.aureus, E.coli, Salmonella sp., Bacillus sp., dan Clostridium perfringens dalam biofilm (Maori \& De, 2010). Kuman patogen pada air pencucian juga dapat mengontaminasi peralatan yang dicuci, sehingga kualitas air pencucian memengaruhi kualitas mikrobiologis peralatan (Marisdayana et al., 2017). Hasil penelitian Bilqis et al. (2016) juga menunjukkan 95\% sampel air pencucian peralatan memiliki angka kuman melebihi persyaratan dan 52,2\% sampel air pencucian positif E.coli.

Proses pencucian yang tidak adekuat dapat menyisakan pangan/minyak serta sejumlah kuman pada permukaan peralatan makan dan minum. Sisa pangan/minyak merupakan media perkembangbiakan bakteri dan jamur, sedangkan sisa kuman dari mulut/tangan konsumen dapat menjadi sumber penularan bagi konsumen lainnya. Beberapa patogen yang teridentifikasi dalam rongga mulut/air liur antara lain Mycobacterium tuberculosis, Bacillus sp., S.aureus, S.epidermidis, E.coli, Haemophilus influenzae, herpes simplex viruses, hepatitis $C$ virus, HIV, SARS-CoV-1, dan SARS-CoV-2 (Corstjens et al., 2016; Zawadzki et al., 2016; Xu et al., 2020). 
Tabel 2. Identifikasi Penyebab dan Tindakan Pengendalian pada Proses Pencucian Peralatan

\begin{tabular}{|c|c|c|c|c|}
\hline No. & Tahapan & Penyebab & $\begin{array}{c}\text { Tindakan Pengendalian yang Sudah } \\
\text { Dilakukan }\end{array}$ & Tindakan Pengendalian yang Diperlukan \\
\hline 1. & $\begin{array}{l}\text { Melakukan } \\
\text { scraping/pre- } \\
\text { cleaning diikuti } \\
\text { dengan pre-rinse }\end{array}$ & $\begin{array}{l}\text { Scraping terlalu kasar menimbulkan } \\
\text { goresan, khususnya scraping dengan } \\
\text { kawat/sendok logam pada peralatan } \\
\text { makan dan minum polimer/porselen }\end{array}$ & $\begin{array}{l}\text { Melakukan scraping apabila masih } \\
\text { terdapat sisa pangan, diikuti pre-rinse }\end{array}$ & $\begin{array}{l}\text { - Melakukan scraping dengan cermat } \\
\text { - Menggunakan sendok/ tongkat } \\
\text { kayu/karet kecil untuk membantu } \\
\text { scraping sebagai pengganti kawat/ } \\
\text { sendok logam } \\
\text { - }\end{array}$ \\
\hline 2. & $\begin{array}{l}\text { Melakukan } \\
\text { perendaman } \\
\text { /soaking }\end{array}$ & $\begin{array}{l}\text { - Sisa pangan/minyak pada permukaan } \\
\text { peralatan yang ter-lanjur mengering } \\
\text { sulit dibersihkan } \\
\text { - Kuman patogen yang sudah terlanjur } \\
\text { berkembang biak masih akan tersisa }\end{array}$ & $\begin{array}{l}\text { Tidak ada tindakan pengendalian yang } \\
\text { sudah dilakukan }\end{array}$ & $\begin{array}{l}\text { Melakukan perendaman peralatan makan } \\
\text { dan minum } 15-30 \text { menit sebelum } \\
\text { pembersihan dengan sabun }\end{array}$ \\
\hline 3. & $\begin{array}{l}\text { Melakukan } \\
\text { pencucian/ } \\
\text { washing }\end{array}$ & $\begin{array}{l}\text { Washing yang tidak cermat pada } \\
\text { beberapa sudut/lekukan yang sulit } \\
\text { dijangkau menim-bulkan adanya sisa } \\
\text { noda }\end{array}$ & $\begin{array}{l}\text { Mencuci peralatan dengan } \\
\text { menggosokkan spons yang sudah } \\
\text { dibasahi air sabun }\end{array}$ & $\begin{array}{l}\text { Melakukan pencucian lebih cermat pada } \\
\text { bagian peralatan yang kontak dengan } \\
\text { pangan, kontak dengan tubuh manusia, } \\
\text { dan bagian permukaan yang tidak } \\
\text { sempurna (bercelah/ } \\
\text { gompal/kasar/penyok, dll.) }\end{array}$ \\
\hline 4. & $\begin{array}{l}\text { Melakukan } \\
\text { pembilasan/rinsing }\end{array}$ & $\begin{array}{l}\text { Pembilasan yang tidak dilakukan penggo- } \\
\text { sokan hingga kesat ataupun kurang dari } \\
\text { lima detik masih menyisakan sabun/ } \\
\text { kotoran/pangan pada permukaan } \\
\text { peralatan makan dan minum }\end{array}$ & $\begin{array}{l}\text { Membilas sabun pada permukaan } \\
\text { peralatan dengan air mengalir bertekanan }\end{array}$ & $\begin{array}{l}\text { - Melakukan pembilasan dengan cermat, } \\
\text { menggosok permukaan peralatan } \\
\text { dengan tangan hingga terasa kesat } \\
\text { (minimal selama lima detik) } \\
\text { - Melakukan cek kebersihan ulang pada } \\
\text { peralatan yang telah dibilas (visual dan } \\
\text { bau sisa sabun) }\end{array}$ \\
\hline 5. & $\begin{array}{l}\text { Melakukan } \\
\text { sanitizing }\end{array}$ & $\begin{array}{l}\text { - Pencucian peralatan menggunakan } \\
\text { sabun/ deterjen saja belum dapat } \\
\text { menjamin peralatan bersih secara } \\
\text { mikrobio-logis, terutama dari E.coli }\end{array}$ & $\begin{array}{l}\text { Tidak ada tindakan pengendalian yang } \\
\text { sudah dilakukan }\end{array}$ & $\begin{array}{l}\text { - Melakukan tahapan saniti-zing dengan } \\
\text { bahan sanitasi (sanitizer) food grade } \\
\text { untuk membunuh/menghilangkan } \\
\text { kuman yang masih ada pada peralatan }\end{array}$ \\
\hline
\end{tabular}




\begin{tabular}{|c|c|c|c|c|}
\hline No. & Tahapan & Penyebab & $\begin{array}{c}\text { Tindakan Pengendalian yang Sudah } \\
\text { Dilakukan }\end{array}$ & Tindakan Pengendalian yang Diperlukan \\
\hline & & $\begin{array}{l}\text { yang teriden-tifikasi pada air untuk } \\
\text { pencucian } \\
\text { - Penggunaan saniti-zer yang tidak tepat } \\
\text { jenis, dosis, suhu, waktu kontak, dan } \\
\text { prosedur pengguna-an dapat } \\
\text { memenga-ruhi efektivitasnya }\end{array}$ & & $\begin{array}{l}\text { makan dan minum, termasuk yang } \\
\text { berasal dari air untuk pencucian } \\
\text { - Memperhatikan dan mema-tuhi } \\
\text { petunjuk penggunaan sanitizer pada } \\
\text { kemasannya }\end{array}$ \\
\hline 6. & $\begin{array}{l}\text { Melakukan } \\
\text { pengeringan } \\
\text { /drying }\end{array}$ & $\begin{array}{l}\text { - Pengeringan/ penuntasan dengan } \\
\text { pengelapan dapat menimbulkan } \\
\text { rekontaminasi apabila serbet sudah } \\
\text { digunakan untuk banyak peralatan/ } \\
\text { permukaan lain } \\
\text { - Pengeringan peralatan yang tidak } \\
\text { sempurna/masih menyisakan tetesan air } \\
\text { akan meningkat-kan kelembaban dalam } \\
\text { tempat penyimpanan dan menjadi } \\
\text { media perkembangbiakan kuman } \\
\text { - Air drying yang tempatnya tidak } \\
\text { terlindung dari debu/bahan } \\
\text { kimia/hewan pengganggu/ percikan } \\
\text { air/sabun, menimbulkan rekontaminasi } \\
\text { peralatan bersih }\end{array}$ & $\begin{array}{l}\text { - Sebagian petugas sudah menyediakan } \\
\text { serbet khusus pengeringan peralatan } \\
\text { basah lebih dari satu buah } \\
\text { - Sebagian peralatan bersih dikeringkan } \\
\text { dengan air drying pada draining board }\end{array}$ & $\begin{array}{l}\text { - Memastikan tempat peniris-an untuk air } \\
\text { drying aman dan mencukupi untuk } \\
\text { mencegah peralatan bersih terkena } \\
\text { percikan air/sabun kembali } \\
\text { - Menunggu hingga peralatan kering } \\
\text { sempurna baru kemudian disimpan dan } \\
\text { tidak perlu dilap } \\
\text { - Jika terpaksa harus mengelap peralatan, } \\
\text { harus menggunakan tisu/serbet } \\
\text { baru/bersih } \\
\text { - Menyediakan minimal dua serbet untuk } \\
\text { satu periode pengeringan dan ada stok } \\
\text { serbet cadangan } \\
\text { - Mencuci serbet minimal satu kali sehari } \\
\text { menggu-nakan air panas lalu } \\
\text { dikeringkan dengan sempurna di } \\
\text { tempat yang aman }\end{array}$ \\
\hline
\end{tabular}


Tabel 3. Analisis Risiko Pengelolaan Peralatan Makan dan Minum Kantin SDN Pakis III dan SDN Pakis V Surabaya

\begin{tabular}{|c|c|c|c|c|c|c|c|}
\hline \multirow{2}{*}{ Tahapan } & \multirow{2}{*}{ Bahaya } & \multicolumn{5}{|c|}{ Penentuan TKK } & \multirow{2}{*}{ Alasan } \\
\hline & & Q1 & Q2 & Q3 & Q4 & TKK & \\
\hline $\begin{array}{l}\text { Melakukan scraping/ } \\
\text { pre-cleaning diikuti dengan } \\
\text { pre-rinse }\end{array}$ & $\begin{array}{l}\text { Biologis: } \\
\text { Angka kuman, E.coli }\end{array}$ & $Y$ & $\mathrm{Y}$ & $\mathrm{Y}$ & $\mathrm{T}$ & TKK & $\begin{array}{l}\text { Scraping yang tidak dikendalikan akan menghambat } \\
\text { proses washing dan dapat memengaruhi efektivitas } \\
\text { pencucian }\end{array}$ \\
\hline $\begin{array}{l}\text { Melakukan } \\
\text { perendaman/soaking }\end{array}$ & $\begin{array}{l}\text { Biologis: } \\
\text { Angka kuman, E.coli }\end{array}$ & $\mathrm{T}$ & $\mathrm{T}$ & $Y$ & Y & $\begin{array}{l}\text { Bukan } \\
\text { TKK }\end{array}$ & $\begin{array}{l}\text { Perendaman tidak dapat menghilangkan bahaya/mem- } \\
\text { bunuh kuman. Sisa pangan pada peralatan di lokasi tidak } \\
\text { terlalu banyak dan tidak sulit dibersihkan }\end{array}$ \\
\hline $\begin{array}{l}\text { Melakukan pencucian/ } \\
\text { washing }\end{array}$ & $\begin{array}{l}\text { Biologis: } \\
\text { Angka kuman, E.coli }\end{array}$ & $\mathrm{Y}$ & Y & $\mathrm{Y}$ & $\mathrm{T}$ & TKK & $\begin{array}{l}\text { Tahapan washing menggunakan bahan sabun } \\
\text { merupakan tahapan yang bertujuan untuk mem- } \\
\text { bersihkan kotoran pada peralatan agar sanitizing } \\
\text { mampu menjamin hilangnya bahaya/ matinya kuman }\end{array}$ \\
\hline $\begin{array}{l}\text { Melakukan pembilasan/ } \\
\text { rinsing }\end{array}$ & $\begin{array}{l}\text { Biologis: } \\
\text { Angka kuman, E.coli }\end{array}$ & $\mathrm{Y}$ & Y & $\mathrm{Y}$ & $\mathrm{T}$ & TKK & $\begin{array}{l}\text { Pembilasan merupakan satu rangkaian yang tidak } \\
\text { terpisah-kan dari tahapan washing yang bertujuan untuk } \\
\text { membersihkan kotoran pada peralatan agar sanitizing } \\
\text { mampu menjamin matinya kuman }\end{array}$ \\
\hline Melakukan sanitizing & $\begin{array}{l}\text { Biologis: } \\
\text { Angka kuman, E.coli }\end{array}$ & $\mathrm{T}$ & Y & $\mathrm{Y}$ & $\mathrm{T}$ & TKK & $\begin{array}{l}\text { Penggunaan sanitizer bertujuan untuk menjamin } \\
\text { hilangnya bahaya/matinya kuman }\end{array}$ \\
\hline $\begin{array}{l}\text { Melakukan } \\
\text { pengeringan/drying }\end{array}$ & $\begin{array}{l}\text { Biologis: } \\
\text { Angka kuman }\end{array}$ & $\mathrm{Y}$ & $\mathrm{T}$ & $\mathrm{Y}$ & $\mathrm{T}$ & TKK & $\begin{array}{l}\text { Pengeringan dengan lap yang kotor/sudah digunakan } \\
\text { berulang kali dapat menyebabkan adanya bahaya lagi } \\
\text { (rekontaminasi) pada peralatan yang sudah dicuci/sudah } \\
\text { bersih }\end{array}$ \\
\hline
\end{tabular}


Identifikasi bahaya yang dilakukan memberi gambaran potensi risiko yang ada pada pengelolaan peralatan makan dan minum di kantin sekolah. Bahaya biologis yang teridentifikasi dapat menimbulkan tiga risiko kesehatan, yaitu risiko kontaminasi patogen pada peralatan, risiko kontaminasi pangan oleh patogen dari peralatan, serta risiko penularan penyakit antar siswa. Apabila risiko-risiko tersebut terjadi, dapat muncul dampak merugikan bagi kesehatan siswa SD sebagai konsumen dengan kerentanan tinggi, antara lain infeksi saluran pencernaan, infeksi penyakit menular, keracunan pangan, dan dapat berakibat pada environmental enteropathy yang berujung pada kondisi stunting (Kemenkes RI, 2018; Watanabe \& Petri, 2016).

\section{Identifikasi Penyebab dan Tindakan \\ Pengendalian yang Diperlukan}

Berdasarkan wawancara saat identifikasi penyebab, adanya gelas yang tidak dicuci adalah karena petugas berpendapat gelas tersebut belum tampak kotor sehingga belum perlu dicuci dan proses penjualan minuman dianggap akan terhambat apabila tiap gelas yang selesai digunakan harus selalu dicuci. Pencucian yang tidak dilakukan menyebabkan sisa pangan yang menempel pada permukaan peralatan semakin banyak, sehingga kuman dapat berkembang biak dan terus menjadi sumber kontaminasi. Selain itu, tidak adanya proses pencucian peralatan sebelum digunakan untuk konsumen lainnya akan mengakumulasi kuman-kuman dari mulut dan tangan para penggunanya. Peralatan makan maupun minum yang tidak dicuci dengan baik merupakan salah satu penyebab terjadinya risiko kontaminasi pangan dan risiko penularan penyakit (Sopandi \& Wardah, 2014; Islamiar et al., 2017).

Perendaman tidak dilakukan karena petugas berpendapat bahwa sisa pangan dapat hilang seluruhnya dengan scraping serta tidak cukup waktu dan tempat untuk perendaman. Demikian pula dengan sanitizing, petugas berpendapat peralatan sudah cukup bersih selama pencucian menggunakan sabun dan sudah tidak ada noda/minyak tersisa. Padahal, peralatan yang secara visual telah bersih dan wangi masih mungkin mengandung patogen. Praktik penyediaan pangan tidak disarankan menggunakan peralatan yang belum disanitasi (Orogu et al., 2017).

Scraping menggunakan sendok/kawat logam pada peralatan berbahan dasar polimer dan porselen dapat membuat goresan/celah kecil pada permukaan peralatan. Adanya celah tersebut ditambah dengan pengaplikasian sabun saat washing yang kurang cermat, dapat menimbulkan sisa pangan/minyak yang menjadi media perkembangbiakan bakteri maupun jamur. Proses pembilasan seharusnya dapat dimanfaatkan untuk memeriksa ulang kebersihan peralatan baik dari sisa kotoran maupun sisa sabun, akan tetapi hal ini tidak dilakukan sehingga ditemukan adanya noda kehitaman pada sudut-sudut peralatan, khususnya pada bibir gelas. Petugas melakukan pengeringan menggunakan lap kain/serbet, karena pengelapan dianggap menjamin kebersihan peralatan. Pengelapan tidak disarankan karena dapat menimbulkan rekontaminasi peralatan yang sudah dibersihkan dan disanitasi, akan tetapi di sisi lain peralatan harus sudah kering sempurna saat disimpan. Metode yang lebih baik adalah air drying pada tempat yang aman dari percikan/kotoran. Apabila peralatan harus dikeringkan segera, pengelapan dapat dilakukan dengan lap kain bersih dan kering yang sering diganti dan direbus (steril), atau lebih baik menggunakan lap sekali pakai seperti tisu (Food Standards Australia New Zealand, 2016).

\section{Analisis Risiko Pengelolaan Peralatan Makan dan Minum}

Scraping yang tidak dilakukan akan menimbulkan sisa pangan/kotoran pada permukaan peralatan dan akan menghambat pembersihan dengan sabun. Selain itu, sisa pangan yang tidak dibersihkan terlebih dahulu akan tercecer di sekitar tempat pencucian dan menjadi sumber kontaminasi. Di sisi lain, scraping yang tidak hati-hati akan menimbulkan goresan/celah kecil pada permukaan peralatan yang rentan menjadi tempat perkembangbiakan mikroorganisme, oleh sebab itu tahap scraping merupakan TKK. Perendaman tidak termasuk dalam TKK karena tidak menjamin hilangnya bahaya, tidak tersedianya tempat dan waktu, serta sisa pangan pada peralatan yang digunakan di lokasi tidak terlalu banyak dan 
tidak sulit dibersihkan saat washing (tidak mengering/mengeras).

Pembersihan menyeluruh pada permukaan peralatan melalui washing dan rinsing adalah tahapan kritis sebelum sanitizing, di mana sanitizing tidak akan berjalan efektif apabila diaplikasikan pada permukaan yang masih kotor. Washing dan rinsing yang dilakukan petugas di lokasi kurang cermat sehingga tampak noda kehitaman pada bagian sudut/lekukan peralatan, oleh sebab itu tahapan washing dan rinsing juga merupakan TKK. Sanitizing merupakan tahapan yang dirancang khusus untuk menghilangkan bahaya/membunuh kuman yang masih ada namun tidak terlihat pada permukaan peralatan. Hasil observasi menunjukkan bahwa sanitizing tidak dilakukan oleh petugas di lokasi, sehingga keseluruhan proses pencucian yang dilakukan menjadi tidak adekuat. Tidak dilakukannya sanitizing meningkatkan risiko masih adanya kuman patogen pada permukaan peralatan, karena terdapat pula peralatan yang ditemukan di berbagai tempat kotor, misalnya di tempat sampah. Hal-hal tersebut menjadi alasan ditentukannya sanitizing termasuk dalam TKK. Bahan desinfektan ataupun sanitizer memang belum umum digunakan oleh petugas kantin sekolah (Syafirah, 2015).

Pengeringan peralatan yang tidak dikendalikan dapat menimbulkan adanya bahaya pada peralatan bersih/rekontaminasi dan tidak ada proses berikutnya yang dapat menghilangkan/mengurangi bahaya tersebut, sedangkan pengeringan sempurna harus tetap dilakukan agar tidak terbentuk biofilm. Masih adanya petugas yang menganggap bahwa pengelapan dapat meningkatkan kebersihan dan tidak mengetahui bahwa lap/serbet dapat menjadi sumber kontaminasi menyebabkan pengeringan yang dilakukan di kedua sekolah perlu mendapat tindakan pengendalian dan termasuk dalam TKK. Lap/serbet merupakan salah satu vehicle paling signifikan dalam kontaminasi silang di area dapur, di mana risiko rekontaminasi oleh kuman patogen akibat pengelapan lebih besar daripada kemungkinan peningkatan kebersihan yang diharapkan (Byrdbredbenner et al., 2013).

\section{SIMPULAN}

Pengelolaan peralatan makan dan minum di kantin sekolah mengandung bahaya biologis (mikrobiologis) yang disebabkan dari proses pencucian. Bahaya mikrobiologis yang teridentifikasi adalah angka kuman peralatan gelas, mangkuk, dan sendok serta kandungan E.coli air pencucian peralatan yang tidak memenuhi syarat. Penyebab terjadinya risiko antara lain yaitu kualitas mikrobiologis air dan tahap pencucian yang tidak adekuat. Tindakan pengendalian yang diperlukan dapat diterapkan pada titik kendali kritis (TKK) yang telah teridentifikasi, yaitu pada tahap scraping, washing, rinsing, sanitizing, dan drying.

Direkomendasikan kepada pihak sekolah untuk menyusun dan mendokumentasikan SOP pengelolaan peralatan makan dan minum, mengirim penjamah makanan mengkuti sertifikasi higiene dan sanitasi, serta meningkatkan fasilitas sanitasi peralatan di kantin sekolah seperti tempat pencucian/sink dengan draining board dan rak penyimpanan yang tertutup. Puskesmas Pakis ataupun Dinas Kesehatan Kota Surabaya dapat memberikan sosialisasi pengelolaan peralatan makan dan minum yang higienis dan saniter di kantin sekolah.

\section{DAFTAR PUSTAKA}

Adley, C. C., \& Ryan, M. P. (2016). The Nature and Extent of Foodborne Disease. In J. BarrosVelazquez (Ed.), Antimicrobial Food Packaging (hal. 1-10). Elsevier. https://doi.org/10.1016/B978-0-12-8007235.00001-2

Astri, A. D. 'Uddina, \& Hariyati, N. (2018). Integrasi Konsep Reduce, Reuse, Recycle dalam Pengelolaan Kantin Apung di SMP Negeri 26 Surabaya. Diambil dari https://jurnalmahasiswa.unesa.ac.id/index.php/ inspirasi-manajemenpendidikan/article/view/23013/21093

BPOM. (2017). Laporan Tahunan Badan POM 2017. Byrd-bredbenner, C., Berning, J., \& Martin-biggers, J. (2013). Food Safety in Home Kitchens: A Synthesis of the Literature. International Journal of Environmental Research and Public Health, 10, 4060-4085.

https://doi.org/10.3390/ijerph10094060 
Corstjens, P., Abrams, W. R., \& Malamud, D. (2016). Saliva and Viral Infections. Periodontology 2000, 70(1), 93-110. https://doi.org/10.1111/prd.12112

Food Standards Australia New Zealand. (2016). A Guide to the Food Safety Standards.

Islamiar, A. N., Narwati, \& Rahayu, U. (2017). Efektivitas Perasan Daun Jeruk Purut terhadap Angka Kuman pada Peralatan Makan Tahun 2017. Gema Kesehatan Lingkungan, 15(3), 5055.

Kemenkes RI. (2018). Buletin Jendela Data dan Informasi Kesehatan: Stunting.

Maori, L., \& De, N. (2010). Bacterial Contamination of Crockery and Cutlery within the Kiosks' Restaurants of the Federal University of Technology, Yola. African Journal of Microbiology Research, 4(3), 147-153. Diambil dari

http://citeseerx.ist.psu.edu/viewdoc/download? doi=10.1.1.852.4217\&rep $=$ rep1\&type $=$ pdf

Marisdayana, R., Putri Sahara, \& Yosefin, H. (2017). Teknik Pencucian Alat Makan, Personal Hygiene terhadap Kontaminasi Bakteri pada Alat Makan. Endurance, 2(3), 376-382. http://doi.org/10.22216/jen.v2i3.2052

Ogba, O. M., Asukwo, P. E., \& Otu-bassey, I. B. (2018). Assessment of Bacterial Carriage on the Hands of Primary School Children in Calabar Municipality, Nigeria. Biomedical Dermatology, 2(6), 1-7. https://doi.org/10.1186/s41702-017$\underline{0017-0}$

Orogu, J. O., Ehiwario, N. J., \& Adebisi, O. O. (2017). Microbiological Assessment of Cutleries. MOJ Bioequiv Availab, 3(6), 159-162. https://doi.org/10.15406/mojbb.2017.03.00054

Purwanti, S., Arundina, A., \& Yanti, S. N. (2015). Perilaku Mencuci Tangan terhadap Angka Koloni Kuman pada Penjamah Makanan di
Kantin Universitas Tanjungpura. Jurnal Vokasi Kesehatan, 1(2), 64-69.

Ray, S. K., Amarchand, R., Srikanth, J., \& Majumdar, K. K. (2011). A Study on Prevalence of Bacteria in the Hands of Children and Their Perception on Hand Washing in Two Schools of Bangalore and Kolkata. Indian Journal of Public Health, 55(4). https://doi.org/10.4103/0019-557X.92408

Sopandi, T., \& Wardah. (2014). Mikrobiologi Pangan. Yogyakarta: Penerbit ANDI.

Syafirah, S. (2015). Higiene Sanitasi dan Keamanan Mikrobiologi Pangan di Kantin Sekolah Dasar Negeri Kecamatan Mulyorejo. Universitas Airlangga.

Watanabe, K., \& Petri, W. A. (2016). Environmental Enteropathy: Elusive but Significant Subclinical Abnormalities in Developing Countries. EBioMedicine, 10, 25-32. https://dx.doi.org/10.1016\%2Fj.ebiom.2016.07.0 $\underline{30}$

Xu, R., Cui, B., \& Duan, X. (2020). Saliva: Potential Diagnostic Value and Transmission of 2019nCoV. International Journal of Oral Science. https://doi.org/10.1038/s41368-020-0080-z

Yushananta, P., \& Usman, S. (2018). The Incidence of Diarrhea in Babies Affected through the Cleanliness of Eating Utensils and Hands. Journal of Medical Science And clinical Research, 6(9). https://doi.org/10.18535/jmscr/v6i9.137

Zawadzki, P. J., Perkowski, K., Starościak, B., Baltaza, W., Padzik, M., Pionkowski, K., \& Chomicz, L. (2016). Identification of Infectious Microbiota from Oral Cavity Environment of Various Population Group Patients as a Preventive Approach to Human Health Risk Factors. Annals of Agricultural and Environmental Medicine, 23(4), 566-569. https://doi.org/10.5604/12321966.1226847 